\title{
Film Culture in Transition
}

\author{
General Editor: Thomas Elsaesser
}

Thomas Elsaesser, Robert Kievit and Jan Simons (eds.)

Double Trouble: Chiem van Houweninge on Writing and Filming, 1994 ISBN paperback 9789053560259

Thomas Elsaesser, Jan Simons and Lucette Bronk (eds.)

Writing for the Medium: Television in Transition, 1994

ISBN paperback 9789053560549

Karel Dibbets and Bert Hogenkamp (eds.)

Film and the First World War, 1994

ISBN paperback 9789053560648

Warren Buckland (ed.)

The Film Spectator: From Sign to Mind, 1995

ISBN paperback $97890535^{6} 131$ 7; ISBN hardcover 9789053561706

Egil Törnqvist

Between Stage and Screen: Ingmar Bergman Directs, 1996

ISBN paperback 978905356137 9; ISBN hardcover 9789053561713

Thomas Elsaesser (ed.)

A Second Life: German Cinema's First Decades, 1996

ISBN paperback $97890535^{6} 172$ o; ISBN hardcover 9789053561836

Thomas Elsaesser

Fassbinder's Germany: History Identity Subject, 1996

ISBN paperback 978905356059 4; ISBN hardcover 9789053561843

Thomas Elsaesser and Kay Hoffmann (eds.)

Cinema Futures: Cain, Abel or Cable? The Screen Arts in the Digital Age, 1998 ISBN paperback 978905356282 6; ISBN hardcover 9789053563120

Siegfried Zielinski

Audiovisions: Cinema and Television as Entr'Actes in History, 1999

ISBN paperback 978905356313 7; ISBN hardcover 9789053563038 
Kees Bakker (ed.)

Joris Ivens and the Documentary Context, 1999

ISBN paperback 978905356389 2; ISBN hardcover 9789053564257

Egil Törnqvist

Ibsen, Strindberg and the Intimate Theatre: Studies in TV Presentation, 1999

ISBN paperback 978905356350 2; ISBN hardcover 9789053563717

Michael Temple and James S. Williams (eds.)

The Cinema Alone: Essays on the Work ofJean-Luc Godard 1985-2000, 2000 ISBN paperback 978905356455 4; ISBN hardcover 9789053564561

Patricia Pisters and Catherine M. Lord (eds.)

Micropolitics of Media Culture: Reading the Rhizomes ofDeleuze and Guattari, 2001

ISBN paperback 978905356472 1; ISBN hardcover 9789053564738

William van der Heide

Malaysian Cinema, Asian Film: Border Crossings and National Cultures, 2002

ISBN paperback $97890535^{6} 519$ 3; ISBN hardcover $97890535^{6} 5^{80} 3$

Bernadette Kester

Film Front Weimar: Representations of the First World War in German

Films of the Weimar Period (1919-1933), 2002

ISBN paperback 978905356597 1; ISBN hardcover 9789053565988

Richard Allen and Malcolm Turvey (eds.)

Camera Obscura, Camera Lucida: Essays in Honor of Annette Michelson, 2003

ISBN paperback 9789053564943

Ivo Blom

Jean Desmet and the Early Dutch Film Trade, 2003

ISBN paperback 978905356463 9; ISBN hardcover 9789053565704

Alastair Phillips

City of Darkness, City of Light: Émigré Filmmakers in Paris 1929-1939, 2003 ISBN paperback 978905356634 3; ISBN hardcover 9789053566336 
Thomas Elsaesser, Alexander Horwath and Noel King (eds.)

The Last Great American Picture Show: New Hollywood Cinema in the 1970s, 2004

ISBN paperback 978905356631 2; ISBN hardcover 9789053564936

Thomas Elsaesser (ed.)

Harun Farocki: Working on the Sight-Lines, 2004

ISBN paperback 978905356635 o; ISBN hardcover 9789053566367

Kristin Thompson

Herr Lubitsch Goes to Hollywood: German and American Film after World War I, 2005 ISBN paperback 978905356708 1; ISBN hardcover 9789053567098

Marijke de Valck and Malte Hagener (eds.)

Cinephilia: Movies, Love and Memory, 2005

ISBN paperback 978905356768 5; ISBN hardcover 9789053567692

Thomas Elsaesser

European Cinema: Face to Face with Hollywood, 2005

ISBN paperback 978905356594 0; ISBN hardcover 9789053566022

Michael Walker

Hitchcock's Motifs, 2005

ISBN paperback 978905356772 2; ISBN hardcover 9789053567739

Nanna Verhoeff

The West in Early Cinema: After the Beginning, 2006

ISBN paperback 9789053568316 ; ISBN hardcover 9789053568323

Anat Zanger

Film Remakes as Ritual and Disguise: From Carmen to Ripley, 2006 ISBN paperback 978905356784 5; ISBN hardcover $978905356785^{2}$

Wanda Strauven

The Cinema of Attractions Reloaded, 2006

ISBN paperback 978905356944 3; ISBN hardcover 9789053569450 
Malte Hagener

Moving Forward, Looking Back: The European Avant-garde and the Invention of Film Culture, 1919-1939, 2007

ISBN paperback 978905356960 3; ISBN hardcover 978905356961 o

Tim Bergfelder, Sue Harris and Sarah Street

Film Architecture and the Transnational Imagination: Set Design in 1930 s

European Cinema, 2007

ISBN paperback 978905356984 9; ISBN hardcover 9789053569801

Jan Simons

Playing the Waves: Lars von Trier's Game Cinema, 2007

ISBN paperback 978905356991 7; ISBN hardcover 9789053569795

Marijke de Valck

Film Festivals: From European Geopolitics to Global Cinephilia, 2007 ISBN paperback 978905356192 8; ISBN hardcover 9789053562161

Asbjørn Grønstad

Transfigurations: Violence, Death, and Masculinity in American Cinema, 2008

ISBN paperback 978908964010 9; ISBN hardcover 9789089640307

Vinzenz Hediger and Patrick Vonderau (eds.)

Films that Work: Industrial Film and the Productivity of Media, 2009 ISBN paperback 978908964013 o; ISBN hardcover 9789089640123

François Albera and Maria Tortajada (eds.)

Cinema beyond Film: Media Epistemology in the Modern Era, 2010 ISBN paperback 978908964083 3; ISBN hardcover 9789089640840

Pasi Väliaho

Mapping the Moving Image: Gesture, Thought and Cinema circa 1900, 2010 ISBN paperback 978908964140 3; ISBN hardcover 978908964141 o

Pietsie Feenstra

New Mythological Figures in Spanish Cinema: Dissident Bodies under Franco, 2011

ISBN paperback 978908964304 9; ISBN hardcover 9789089643032 
Eivind Røssaak (ed.)

Between Stillness and Motion: Film, Photography, Algorithms, 2011 ISBN paperback 978908964212 7; ISBN hardcover 9789089642134

Tara Forrest

Alexander Kluge: Raw Materials for the Imagination, 2011 ISBN paperback 978908964272 1; ISBN hardcover 9789089642738

Belén Vidal

Figuring the Past: Period Film and the Mannerist Aesthetic, 2012 ISBN 978908964282 o

Bo Florin

Transition and Transformation: Victor Sjöström in Hollywood 1923-1930, 2012 ISBN 9789089645043

Erika Balsom

Exhibiting Cinema in Contemporary Art, 2013

ISBN 9789089644718

Gilles Mouëllic

Improvising Cinema, 2013

ISBN 97890896445517

Christian Jungen

Hollywood in Canne\$: The History of a Love-Hate Relationship, 2014 ISBN 9789089645661

Michael Cowan

Walter Ruttmann and the Cinema of Multiplicity: Avant-Garde FilmAdvertising-Modernity, 2014

ISBN $978908964585^{2}$

Temenuga Trifonova

Warped Minds: Cinema and Psychopathology, 2014

ISBN 9789089646323

Christine N. Brinckmann

Color and Empathy: Essays on Two Aspects of Film, 2014

ISBN 9789089646569 
François Albera and Maria Tortajada (eds.)

Cine-Dispositives: Essays in Epistemology Across Media, 2015

ISBN 9789089646668

Volker Pantenburg

Farocki/Godard: Film as Theory, 2015

ISBN 9789089648914

Paul Cuff

A Revolution for the Screen: Abel Gance's NAPOLÉON, 2015

ISBN 9789089647344

Scott Loren and Jörg Metelmann (eds.)

Melodrama After the Tears: New Perspectives on the Politics of Victimhood, 2015

ISBN 9789089646736

Steve Choe

Sovereign Violence: Ethics and South Korean Cinema in the New Millennium, 2016

ISBN 9789089646385

Melis Behlil

Hollywood is Everywhere: Global Directors in the Blockbuster Era, 2016 ISBN 9789089647399

Thomas Elsaesser

Film History as Media Archaeology: Tracking Digital Cinema, 2016 ISBN 9789462980570

Michael Walker

Modern Ghost Melodramas: 'What Lies Beneath', 2017

ISBN 9789462980167

Steffen Hven

Cinema and Narrative Complexity: Embodying the Fabula, 2017 ISBN 9789462980778 
Alexandra Seibel

Visions of Vienna: Narrating the City in 1920 and 1930 Cinema, 2017 ISBN 9789462981898

Rossella Catanese

Futurist Cinema: Studies on Italian Avant-garde Film, 2018 ISBN $97890896475^{2} 8$

Adrian Martin

Mysteries of Cinema: Reflections on Film Theory, History and Culture 1982-2016, 2018 ISBN 9789462986831

Paula Albuquerque

The Webcam as an Emerging Cinematic Medium, 2018 ISBN 9789462985582 
